\title{
Public Debt and Economic Growth: The Nigerian Experience
}

\author{
Chukwuemeka Nwamuo, Ph.D ${ }^{1}$, Samuel Agu, Ph.D ${ }^{2}$ \\ ${ }^{I}$ Department of Economics, Obong University, Obong Ntak, Akwa Ibom state - Nigeria \\ ${ }^{2}$ Department of Banking and Finance, University of Nigeria, Nsukka, Enugu campus
}

\begin{abstract}
The study investigated the impact of public debt on the economic growth in Nigeria. Annual time series data were obtained from theCentral Bank of Nigeria Statisticalfor the period 1981to2019 on the variables used for the study. Unit root test was conducted using Augmented Dickey-Fuller test and Phillips-Perrontest techniques and the results showed that the variables werestationary though at different levels. Cointegration test was also conducted using Johansen cointegration test method and the result showed that the variables in the model were co-integrated meaning that the variables have a long run relationship. The error correction mechanism showed that the coefficient of multiple determination $\left(R^{2}\right)$ in the overparameterized model was 0.890783 while it was 0.846548 in the parsimonious model. The short run regression result showed that external debt has a negative and insignificant impact on the economic growth in Nigeria. The short run result also showed that domestic debt has a positive and significant impact on the economic growth in Nigeria while credit to private sector has a negative and insignificant impact on the economic growth in Nigeria.The result from long run dynamic analysis revealed thatexternal debt has a negative and insignificant impact on the economic growth in Nigeria while domestic debt has a positive and significant impact on the economic growth in Nigeria. The long run dynamic analysis also showed that credit to private sector has a positive and significant impact on the economic growth in Nigeria. Based on these findings, it was recommended that government should reduce the rate at which it takes external loans to finance its activities. Moreover, domestic debts should be properly managed by channeling it towards those activities that will stimulate economic growth.
\end{abstract}

Keywords: Public debt, External debt, Domestic debt, Economic growth.

\section{INTRODUCTION}

$\mathrm{P}$ ublic debt is one of the sources of revenue for the government when projected expenditure exceeds receipts and it is generally referred to as the total amount of money a government owes her citizens, other governments,agencies or organizations (Okafor and Obasi, 2011).Public debt also refers to borrowing by a government from within the country or from abroad, from private individuals or association of individuals or from banking and non-banking financial institutions. Abel and Bernanke (2005) opined that government or public debt is the total value of government bonds outstanding at any particular time however, Bade and Parking (2004) defined public or national debt as the total amount that the federal government has borrowed to make expenditures that exceed tax revenue - to run a government budget deficit. Public debt is internal/domestic when it arises from borrowing from individuals and firms within a country while it is external when it is owed to individuals and organizations (firms) outside the country (Nwaeze,2005). Public debt is productive when it is expected to create assets which will yield income sufficient to pay the principal and interest on the loan while loans raised for war do not create any asset, they are dead weight and are regarded as unproductive. Short term loans are repayable after short interval of time while long term loans are payable after a long time covering several years (Dewett and Navalur, 2012).

\subsection{Statement of problem}

Government borrowing becomes indispensable when the conventional revenue sources (tax and non-tax) are inadequate in financing government expenditures. Such borrowing can come from internal or external sources. This is necessary in order to boost domestic investment and hence accelerate economic growth and development (Anyanwu, 1993). Government borrows in order to close the resource gap between savings and investment (Likita, 1999). Government also borrow to finance investment and infrastructural projects which provides the fundamental basis for further economic production and growth among others. (Nwaeze, 2005). In Nigeria, both domestic and external debt have witnessed an in increase over the years. Available data showed that domestic debt increased from $\$ 11.19$ billion in 1981 to $\$ 36.79$ billion in 1987 while external debt increased from $\$ 2.33$ billion to N100.79 billion within the same period of time. The data also revealed that domestic debt also increased from N497.73billion in 1995to $\$ 6537.54$ billion in 2012 while external debt increased from $\$ 716.87$ billion to $\$ 3325.90$ within the same period. Between 2015 and 2019, domestic debt increased from $\$ 8837.0$ billion to 142272 billion while external debt increased from $\$ 2111.51$ to $\$ 9022.42$ billion (CBN statistical bulletin, 2019). Given that one of the objectives of increases in public debt is to stimulate economic growth, this huge increase in public debt is expected to generate a corresponding increase in economic growth in Nigeria, unfortunately, increases in public debt has not been able to generate a meaningful growth in Nigeria. The study therefore seeks to investigate the impact of public debt on economic growth in Nigeria. 


\subsection{Objectives of the study}

The broad objective of the study was to investigate the impact of public debt on the economic growth of Nigeria. The specific objectives of the study were:

i. To investigate the impact of external debt on the economic growth in Nigeria

ii. To examine the impact of domestic debt on the economic growth in Nigeria

iii. To investigate the impact of private sector credit on the economic growth in Nigeria

\subsection{Hypothesis of the study:}

In order to guide the study, the following null hypotheses were formulated:

$H O_{I}$ : External debt does not have any impact on economic growth in Nigeria.

$\mathrm{HO}_{2}$ : Domestic debt does not have any impact on economic growth in Nigeria.

$\mathrm{HO}_{3}$ : Credit to private sector does not have any impact on economic growth in Nigeria.

\section{LITERATURE REVIEW}

\subsection{Trend Analysis of external debt and domestic debt in} Nigeria

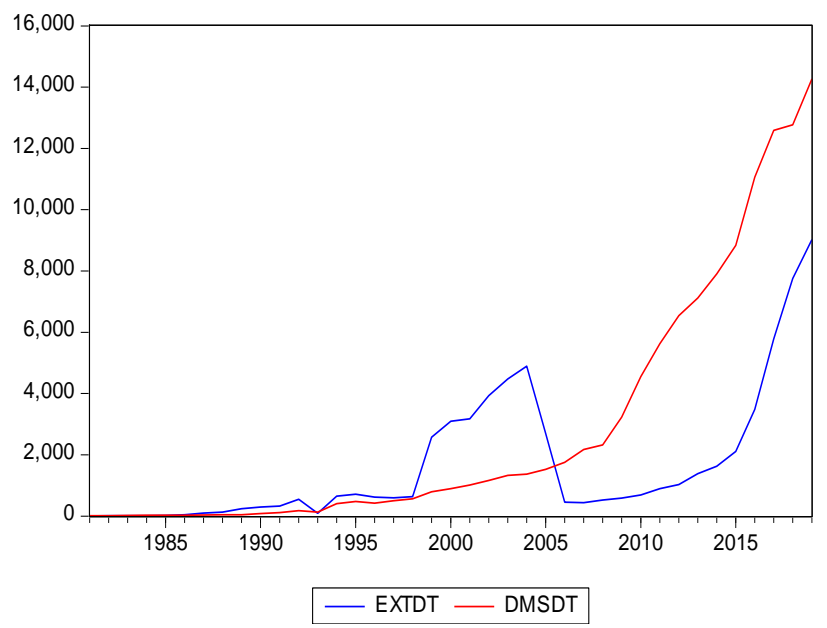

Figure 1: Trend analysis

Source: Computer analysis of E-views 9 and data from CBN statistical bulletin 2019

Trend analysis of external debt and domestic debt of Nigeria presented in figure 1 showed that external debt witnessed an increase from 1981 when it was 2.33 billion to 1993 when the figure stood at $\$ 89.97$ billion but witnessed a sharp fall in 1993 when its figure stood at $\$ 87.97$ billion. From 1996 it started rising when the figure was $\$ 617.32$ billion till 2004 when it witnessed a sharp rise to 4890.27 billion after which in 2005 it begins to decline continuously when the figure was \$2695.07 billion till 2007 when the figure fell to $\$ 438.89$ billion. From 2008, when it started to rise again when the figure was $\$ 523.25$ billion to 2019 when the figure rose to \$922.42 billion.

The trend analysis also revealed that domestic debt increased continuously from 1981 when the figure stood at 11.19 billion to 1992 when the figure stood at $\$ 177.96$ billion. In 1993 , it fell slightly to $\$ 127$ billion and begins to rise continuously in 1994 when the figure stood at $\$ 407.58$ till 2019 when the figure was 14272.64 billion.

\subsection{Theoretical literature}

\subsubsection{Smith's theory of public debt}

Smith argues that governments should not run budget deficits, because the accumulation of debt is considered "pernicious" for the nation even if all of it is owed to domestic investors. In fact, Smith attacks the mercantilist notion according to which the payment of interest on public debt is like "the right hand which pays the left". For Smith this is an "apology founded altogether on the sophistry of the mercantile system". The reason is that soon the need to redeem the debt will lead to increased taxation, causing the flight of domestic capital and the devaluation of the currency with negative effects on the remaining domestic producers. The debt, according to Smith, severely retards the "natural progress of a nation towards wealth and prosperity" since resources that could be used productively from the private sector of the economy are diverted by the state in order to finance its unproductive activities. Consequently, Smith proposed balanced budgets, where all government expenditures are financed by taxation. Budget deficits can be justified only in emergencies, as those that arise during wars or natural disasters. In such circumstances, Smith argues that the method of financing public expenditures (i.e., via taxation or issue of public bonds) is crucial for capital accumulation (Tsoulfidis, 2007).

\subsubsection{Ricardo's public debt theory}

Ricardo shares Smith's views on the unproductive character of state expenditures and on the notion that their financing via public borrowing decreases the investible product and, therefore, it becomes detrimental to society's capacity to accumulate wealth. Nevertheless, many modern economists attribute to him the idea of the equivalence of the two forms of financing in the so-called Ricardian Equivalence Theorem. This theorem ascribes to Ricardo the view that taxation and public borrowing constitute essentially equivalent forms of financing public expenditures. The rationale behind this view is that the government is expected at some future time to redeem its debt. If we now suppose a closed economy the repayment of debt will take place via increased future taxation, which means that on the basis of the rational expectations hypothesis individuals increase their savings buying the bonds that have been issued by the government. In other words the amount of savings matches the size of public deficit and, therefore, the interest-rate remains the same, which means that there is no crowding out effect of private investments from public expenditures and, therefore, the 
overall demand remains the same together with the other real variables of the economy. There is a similar operating mechanism in the case of an open economy, where the redemption of public debt takes place via the sale of assets to international institutional agents. Such a possibility raises, once again, the question of the limited future government income and, hence, the inevitable future increase of taxation (Tsoulfidis, 2007).

\subsection{Conceptual literature}

Public debt is one of the means to finance government revenue. When government expenditure exceeds its receipts, it borrows from the public. Thus, borrowing or taking loans from the public is called public debt. Public debt as a source of government revenue is different from other sources of public revenue such as taxes, fees etc. in the case of public debt, the government has to pay interest and repay the principal to the public. But nothing is required to be paid by the government in the case of other sources of revenue (Jinghan, 2010). Samuelson and Nordhaus (2010) opined that the government debt (sometimes called the public debt consists of the total or accumulated borrowings by the government. Njoku (2009) argued that public debt is a debt which a country owes its citizens or to other countries, or external organizations.Anyanwu(2003) defined public debt as the debt owned by the nations to the rest of the world. According to Dewett andNavalur (2012) public debt refers to borrowing by a government from within the country or from abroad, from private individuals or association of individuals or from banking and non-banking financial institutions.

Public debt is of various kinds. They include the following: internal debt. Internal debt/domestic is raised from within the country (Dewett and Navalur, 2012). Jinghan (2010), opined that internal/domestic debt is that debt which is raised by the government from individuals, etc within the country. According to Okafor and Obasi (2011), internal or domestic debt is that debt which is raised by the government from individuals, firms and institutions within the country. Anyanwu (2003) defined domestic debt as the total amount of money owed by the governments to the financial institutions, government and other bodies residing in the country. Dewett and Navalur (2012) opined that external debt is the debt owed to foreigner or foreign governments or institutions while according to Jhinghan (2010) in the case of external debt, the government borrows from persons or institutions outside the country.

Public debt also varies and as such can further be classified as under:

- Voluntary debt and compulsory debt: The voluntary debts are loans which are freely given to the government. All public debts are without coercion or force except during emergencies or war. However public debts incurred during crises when people are compelled to lend or buy government bonds is referred to as compulsory debt.
- Redeemable debt and irredeemable debt: Redeemable debt is that which is repayable by the government after a fixed period of time. The interest is paid as agreed but the principal is paid only on maturity. On the other hand, irredeemable debt are debts whose principal are not repaid on maturity. Interest is regularly paid for a period agreed which is normally long enough to cover the principal amount given. However, debts incurred during war can be treated as non-redeemable.

- Funded debt and unfunded debt: funded debt is an interest-bearing long-term loan to the government. With clear terms, and conditions of repayment stated in the debt instrument. (certificate), the government prepares a way of repayment at maturity. But unfunded debt is for a short period usually less than a year a $\mathrm{d}$ its repayment does not require any special arrangement. It is repaid from current receipts.

- Productive debt and unproductive debt: productive debts are debts that are fully covered by assets of equal or greater value. And the source of money for payment of interest is the income generated from the project. While unproductive debt are debts not backed up directly with any existing income generating assets like debts incurred to finance budget deficit, war, rehabilitation of earthquakes or flood victims etc (Okafor and Obasi, 2011),

The major sources of Nigeria's external debts include:

- The Paris club of creditors: this represents only government guaranteed credits. The countries involve guaranteed the export activities of their nationals through official export credit agencies. if the recipient nation's government is unable to pay the foreign exchange equivalent of the domestic currency cover paid by the importer, it becomes government debt owed to the creditor nations. Members of the club include United States of America, United Kingdom, Federal Republic of Germany, France and Canada.

- London club of creditors: they are mainly uninsured and unguaranteed debts of commercial banks in industrial countries to nationals of debtor nations. Members of the club are the commercial banks.

- Multilateral creditors: these are international institutions funded by member nations that provide credit for development purposes. Example of such institutions include: The World Bank, International Monetary Fund, African Development Bank, International Development Association International Finance Corporation.

- Promissory Note Creditors: these are uninsured trade credits arising mainly from trade arrears. The debts are refinanced by the issuance of promissory notes to the creditors by the debtor nation. 
- Bilateral and private sector creditors: a bilateral credit is provided by a government to another government usually for development purposes. Private sector credits are usually from commercial banks and are short-term in nature (Chinweoke,2014).

The instruments used for domestic borrowing according to Njoku (2009) include:

- $\quad$ Treasury bills: these are debt instruments or I.O. Us of the federal government. The federal government of Nigeria uses a treasury bill as an instrument of borrowing short term, say 91-days, from the prospective lenders mostly banks pending the collection or receipt of government revenue from various taxes. Treasury bills are usually issued and sold by the Central Bank of Nigeria (CBN) on behalf of the federal government.

- Treasury certificate: this is a sister debt instrument to the government treasury bill. Treasury certificate is a medium-term federal government security which matures after a period of one to two years. It is issued by the CBN on behalf of the federal government, and its issuance is about two to three times a year. It is designed to bridge the gap between the 91-day treasury bill and the longterm government securities such as development stocks and bonds.

- Eligible development stocks: these are federal government stocks which are usually issued by the CBN on behalf of the federal government, each with a maturity of not more than three years. Any eligible development stocks bought by a bank count as the bank's liquid assets in its calculation of the statutory liquidity ratio.

- Bond issue: this is an instrument of indebtedness issued by a long-term borrower in favour of a lender or bond holder to exercise a claim on the assets of the borrower. It is an acknowledgement of indebtedness of the borrower.

- Revenue bond: this is issued at the capital or bond market by the state or local government to raise long term funds for the financing of development projects. Revenue bond is usually backed with an undertaking giving by the borrowing entity to utilize all expected revenues or part thereof which are to be generated from the project being financed in direct liquidation of the borrowing.

- General obligations bond: this type of bond is normally issued by a state or local government to raise funds for the construction of roads and erection of public buildings. It has to be backed by a full credit position of the issuer or by the state's tax generating power and capacity. This means that where a state government issues a general obligations bond, the rating of such bond will be based on and limited to economic resources of tax payers in the state and the state's share of revenue from the federation account.

Okafor and Obasi (2011) argued that the internal sources of public borrowing include: borrowing from individuals by selling bonds, borrowing from non-banking financial institutions by selling bonds to them, borrowing from commercial banks and borrowing from central bank.According to Likita (1999) several factors have been identified as major contributory reasons for the existence of public debt in Nigeria. The factors include oil price shock, project viability rise in interest rate, international economic recession and neglect of non-oil sector.

\subsection{Empirical literature}

Alagba and Eferakeya (2019) investigated the effect of public debts on economic growth of Nigeria for the period of thirtyeight (38) years, 1981 to 2018. Data used in the study were collected from Central Bank of Nigeria Statistical bulletin and Debt Management Office. Among the objectives of the study was to: analyze the effect of domestic debts on the economic growth of Nigeria and evaluate the effect of foreign debts on the economic growth of Nigeria. The findings of the study showed that domestic debts of the Federal government of Nigeria is positive and statistically significant to economic growth of Nigeria while foreign debts contribute less to the economic growth of the country. Cost of debts servicing is significant and has a negative effect on economic growth. The study therefore concludes that the Federal government should reduce the rate at which it results to loans, especially foreign loans as a means of financing budget deficits.

Favour et.al (2017) empirically analyzed the relationship between public debt and economic growth inNigeriafrom 1980-2015. The study adopted Vector Error Correction Model (VECM) approach ofeconometric dataanalysis. The variables used in the study include real gross domestic product(RGDP), foreign debt, domesticdebt and domestic private savings. The results of the studyindicated that: (i) External debt have significant negative impact on economic growth within theperiod under study. (ii) Domestic debt (DMD) has significant negative relationship with economicgrowth within the period under consideration. (iii) External debt and domestic debt granger causeRGDP in Nigeria with causality running from external debt and domestic debt to RGDP. Theimplication of this result is that the negative correlation between debt stocks (external debt anddomestic debt) and economic growth which is contrary to a prior expectation may be highlightingthemisappropriation and wrong application (corrupt practices) of the borrowed funds. Based onfindings, the study recommended among others that that government should reduce external debt andthe ones obtained should be strictly used for purposes intended to ensure positive effect.

Akhanolu et.al (2018) carried out a study that focused on the Nigerian government's debt and itsimpact on economic 
growth from 1982-2017 using the two-stage least square regression. For the first equation, of the study, both internal and external debt and their lags were regressed against GDP, the result showed that externalnegatively impacts the economy while internal debtpositively does the same. For the second equation of the study, GDP total savings deposits in the Nigerian deposit money banks and capital expenditure were regressed againstinternal debt, the result showed that all the variables have significant relationship with internal debt. The study therefore, recommended that $f$ Corruption of borrowed funds should be tackled at all cost and also, governmentshould minimize external borrowing, since, it impacts the economy negatively.

Ajayi and Edewusi (2020) examined the effect of public debt on economic growth of Nigeria. Specifically, the study determined the impact of domestic debt on the economic growth of Nigeria; assessed the effect of external debt on the economic growth of Nigeria and analyzed the relationship between public debt and the economic growth of Nigeria. Secondary time series data spanning thirty-seven years (19822018) was gathered in the study. Data gathered in the study was estimated using descriptive statistics, unit root test, Johansen co-integration test and vector error correction model. Findings from the study suggests that external debt exerts a negative long run and short run effect on economic growth of Nigeria and domestic debt was ascertained to exert positive long run and short run effect on economic growth of Nigeria. Based on these findings, the study suggested that policy makers should integrate appropriate measures towards ensuring suitable management of domestic debts; government should ensure that contracted national debts are directed towards encouraging investment in the country and government through necessary monitoring committees should ensure that national debts are directed toward the provision of basic amenities and services required for the development of communities and societies of the nation.

Egbetunde (2012) examined the causal nexus between public debt and economic growth in Nigeria between 1970 and 2010 using a Vector Autoregressive (VAR). The variables used in the study were tested for stationarity using the Augmented Dickey Fuller and Philip Perron test. The result showed that the variables were stationary at first differencing. Cointegration test was also performed and the result revealed the presence of co-integration between public debt and economic growth. The co-integration results showed that public debt and economic growth have long run relationship. The findings of the VAR model revealed that there is a bi-directional causality between public debt and economic growth in Nigeria. The study concluded that public debt and economic growth have long run relationship, and they are positively related if the government is sincere with the loan obtained and use it for the development of the economy rather than channel the funds to their personal benefit.

Emmanuel (2012) examined the impact of public debt on economic growth using Nigeria as a case study. An analysis of the long-run relationship and impact of debt from the perspective of the value impact and proportional impact was done. The value impact variables used in the study included the external debt value, domestic debt value, total debt value and budget deficit figures. The proportional impact variables were ratios of the value impact to the gross domestic product (GDP). An augmented Cobb Douglas model was used and subsequently a dynamic version of the functional relationship was estimated using Co-integration technique to capture the long-run impact of debt variables on economic growth. The result showed that the joint impact of debt on economic growth is negative and quite significant in the long-run though in the short-run the impact of borrowed funds and coefficient of budget deficit is positive. In the study, the speed at which the short-run equation converges to equilibrium in the longrun as shown by the Error Correction Mechanism coefficient was found to be slow. The conclusion from the study was that though in the short-run the impact of borrowed fund on the Nigerian economy was positive, the impact of debt in the long-run depressed economic growth as a result of incompetent debt management.

Khan et.al (2016) explored the impact of public debt on economic growth of Pakistan. the study used augmented Solow growth Model. To test the model, bound test for cointegration was applied on time series data that cover the period from 1972 to 2013 . The empirical results of the study suggested that public debt and economic growth has positive but statistically insignificant relationship. The control variables i.e., population growth entered in the model with expected negative sign while human capital and private investment bear their expected positive signs and were also statistically significant. This indicated that human capital and private investment play a vital role in the growth and development of an economy.

Mathew and Mordecai (2016) examined the impact of public debt on economic development of Nigeria using annual time series data spanning 1986 to 2014. The study employed the Augmented Dickey-Fuller test, Johansen co-integration test, Error Correction Method (ECM) and the Granger Causality test. The Johansen co-integration test results revealed the presence of a long-run relationship among the variables viz; external debt stock, domestic debt stock, external debt servicing, domestic debt servicing and economic development (proxied with GDP per capita) in Nigeria. The ECM results revealed that external debt stock and external debt servicing have insignificant negative relationship with economic development in Nigeria, however, domestic debt stock has a direct and significant relationship with economic development while domestic debt service payment was significant but inversely related to economic development in Nigeria. The lagged error correction terms in ECM 1 and ECM 2 equations are high and statistically significant judging from its high and negatively signed coefficient. The study therefore recommended that the government should reduce the level of external debt it accumulates overtime, but domestic debt 
accumulation would contribute significantly to the development of the economy.

\section{METHODOLOGY}

Multiple regression analysis was used in the study. Time series data spanning from 1981 to 2019 was sourced from the Central Bank of Nigeria statistical bulletin. The data was analysed using E-views 9

\subsection{Model specification}

In order to investigate the impact of public debt on the economic growth of Nigeria, the model for this study was specified thus;

$\mathrm{RGDP}=\mathrm{f}($ EXTDT, DMSDT, CPS $) \ldots(1)$

Where:

RGDP $=$ Real Gross Domestic Product (proxy for economic growth)

EXTDT $=$ External debt

DMSDT $=$ Domestic debt

CPS $=$ Credit to private sector

The model in its econometric linear form can be written as:

RGDP $=b_{0}+b_{1}$ EXTDT $+b_{2}$ DMSDT $+b_{3}$ CPS $+U$.

$\mathrm{U}=$ stochastic or random error term

bo $=$ constant intercept

$b_{1}-b_{3}=$ coefficients of associated variables

The model in the log linear form can be expressed as:

$\operatorname{LogRGDP}=b_{0}+b_{1} \operatorname{LogEXTDT}+b_{2} \operatorname{LogDMSDT}+$

$\mathrm{b}_{3} \log \mathrm{CPS}+\mathrm{U}--(3)$

Where:

Log = natural logarithm

The Augmented-Dickey Fuller (ADF) and Phillips-Perron unit root tests were employed to ensure data stationarity and avoid the problem of spurious regression since the data for the analysis is time series. The Johansen test for co-integration was also employed to investigate whether there is existence of long run relationship among the variables in the model.

Table 1.1 Result of Augmented Dickey-Fuller unit root test

\begin{tabular}{|c|c|c|c|c|c|}
\hline Variables & $\begin{array}{l}\text { ADF test } \\
\text { statistic }\end{array}$ & $\begin{array}{c}1 \% \\
\text { critical } \\
\text { value }\end{array}$ & $\begin{array}{c}5 \% \\
\text { critical } \\
\text { value }\end{array}$ & $\begin{array}{c}10 \% \\
\text { critical } \\
\text { value }\end{array}$ & $\begin{array}{l}\text { Order of } \\
\text { integration }\end{array}$ \\
\hline RGDP & $\begin{array}{c}- \\
4.4811452 \\
\end{array}$ & -3.65588 & $\begin{array}{c}- \\
2.941145\end{array}$ & $\begin{array}{c}- \\
2.609066\end{array}$ & $1(0)$ \\
\hline EXTDT & -6.413553 & $\begin{array}{c}- \\
4.243644 \\
\end{array}$ & $\begin{array}{c}- \\
3.544284 \\
\end{array}$ & $\begin{array}{c}- \\
3.204699 \\
\end{array}$ & 1(2) \\
\hline DMSDT & -4.279513 & $\begin{array}{c}- \\
4.226815 \\
\end{array}$ & $\begin{array}{c}- \\
3.536601 \\
\end{array}$ & $\begin{array}{c}- \\
3.200320 \\
\end{array}$ & 1(1) \\
\hline CPS & -4.551174 & $\begin{array}{c}- \\
4.234972\end{array}$ & $\begin{array}{c}- \\
3.540328\end{array}$ & $\begin{array}{c}- \\
3.202445\end{array}$ & 1(1) \\
\hline
\end{tabular}

Source: Author's computation
Table 1.2 Result of Phillips-Perronunit root test

\begin{tabular}{|c|c|c|c|c|c|}
\hline Variables & $\begin{array}{l}\text { PP test } \\
\text { statistic }\end{array}$ & $\begin{array}{c}1 \% \\
\text { critical } \\
\text { value }\end{array}$ & $\begin{array}{c}5 \% \\
\text { critical } \\
\text { value }\end{array}$ & $\begin{array}{c}10 \% \\
\text { critical } \\
\text { value }\end{array}$ & $\begin{array}{l}\text { Order of } \\
\text { integration }\end{array}$ \\
\hline RGDP & $\begin{array}{c}- \\
6.121030\end{array}$ & $\begin{array}{c}- \\
4.219126\end{array}$ & $\begin{array}{c}- \\
3.533083\end{array}$ & $\begin{array}{c}- \\
3.198312\end{array}$ & $1(0)$ \\
\hline EXTDT & $\begin{array}{c}- \\
12.84489 \\
\end{array}$ & $\begin{array}{c}- \\
4.243644 \\
\end{array}$ & $\begin{array}{c}- \\
3.544285 \\
\end{array}$ & $\begin{array}{c}- \\
3.204699 \\
\end{array}$ & $1(2)$ \\
\hline DMSDT & $\begin{array}{c}- \\
4.279513 \\
\end{array}$ & 4.226815 & $\begin{array}{c}- \\
3.536601 \\
\end{array}$ & 3.200320 & 1(1) \\
\hline CPS & $\begin{array}{c}- \\
4.553768 \\
\end{array}$ & $\begin{array}{c}- \\
4.234972 \\
\end{array}$ & $\begin{array}{c}- \\
3.540328 \\
\end{array}$ & $\begin{array}{c}- \\
3.202445 \\
\end{array}$ & 1(1) \\
\hline
\end{tabular}

Source: Author's computation

The Augmented Dickey-Fuller unit root test result presented on table 1.1 and the Phillips-Perron unit root test result presented on table 1.2 showed that RGDP was stationary at levels at $1 \%, 5 \%$ and $10 \%$. The Augmented Dickey-Fuller and Phillips-Perron unit root test result showed that EXTDT was stationary after the second difference at $1 \%, 5 \%$ and $10 \%$. The unit root tests also showed that DMSDT and CPS were all stationary after the first difference at $1 \%, 5 \%$ and $10 \%$. This is because their various ADF test statistic and PP test statistic was greater than their various $1 \%, 5 \%$ and $10 \%$ criticalvalues in absolute terms.

Table 2: Johansen co-integration test result

\begin{tabular}{|c|c|c|c|c|}
\hline \multicolumn{3}{|c|}{ Sample (adjusted): 19832018} & & \\
\hline \multicolumn{4}{|c|}{ Included observations: 36 after adjustments } & \\
\hline \multicolumn{4}{|c|}{ Trend assumption: Linear deterministic trend } & \\
\hline \multicolumn{3}{|c|}{ Series: RGDP EXTDT DMSDT CPS } & & \\
\hline \multicolumn{5}{|c|}{ Lags interval (in first differences): 1 to 1} \\
\hline \multicolumn{4}{|c|}{ Unrestricted Cointegration Rank Test (Trace) } & \\
\hline $\begin{array}{l}\text { Hypothesi } \\
\text { zed }\end{array}$ & & Trace & 0.05 & \\
\hline $\begin{array}{l}\text { No. of } \\
\mathrm{CE}(\mathrm{s})\end{array}$ & $\begin{array}{l}\text { Eigenvalu } \\
\mathrm{e}\end{array}$ & Statistic & $\begin{array}{l}\text { Critical } \\
\text { Value }\end{array}$ & Prob.** \\
\hline None * & 0.651181 & 62.78499 & 47.85613 & 0.0011 \\
\hline At most 1 & 0.364064 & 24.86975 & 29.79707 & 0.1662 \\
\hline At most 2 & 0.191055 & 8.574093 & 15.49471 & 0.4062 \\
\hline At most 3 & 0.025807 & 0.941234 & 3.841466 & 0.3320 \\
\hline \multicolumn{5}{|c|}{ Trace test indicates 1 cointegrating eqn(s) at the 0.05 level } \\
\hline \multicolumn{5}{|c|}{$*$ denotes rejection of the hypothesis at the 0.05 level } \\
\hline \multicolumn{5}{|c|}{ Unrestricted Cointegration Rank Test (Maximum Eigenvalue) } \\
\hline $\begin{array}{l}\text { Hypothesi } \\
\text { zed }\end{array}$ & & $\begin{array}{l}\text { Max- } \\
\text { Eigen }\end{array}$ & 0.05 & \\
\hline $\begin{array}{l}\text { No. of } \\
\text { CE(s) }\end{array}$ & $\begin{array}{c}\text { Eigenvalu } \\
\mathrm{e}\end{array}$ & Statistic & $\begin{array}{l}\text { Critical } \\
\text { Value }\end{array}$ & Prob.** \\
\hline None * & 0.651181 & 37.91524 & 27.58434 & 0.0017 \\
\hline At most 1 & 0.364064 & 16.29566 & 21.13162 & 0.2081 \\
\hline At most 2 & 0.191055 & 7.632859 & 14.26460 & 0.4172 \\
\hline At most 3 & 0.025807 & 0.941234 & 3.841466 & 0.3320 \\
\hline \multicolumn{5}{|c|}{$\begin{array}{l}\text { Max-eigenvalue test indicates } 1 \text { cointegrating eqn(s) at the } 0.05 \\
\text { level }\end{array}$} \\
\hline \multicolumn{5}{|c|}{$*$ denotes rejection of the hypothesis at the 0.05 level } \\
\hline$* * \mathrm{MacK}$ & inon-Haug-N & chelis $(1999$ & -values & \\
\hline
\end{tabular}

Source: Computer analysis using EViews 9 
The trace test indicates that there is 1 co-integrating equation at 0.05 levels. Mac-eigenvalue test equally indicates that there is 1 co-integrating equations at 0.05 levels. All these results showed that the variables are cointegrated, that is, RGDP has a long run relationship with DMSDT, EXTDT and CPS.

Table 3: Test for the stability of the model

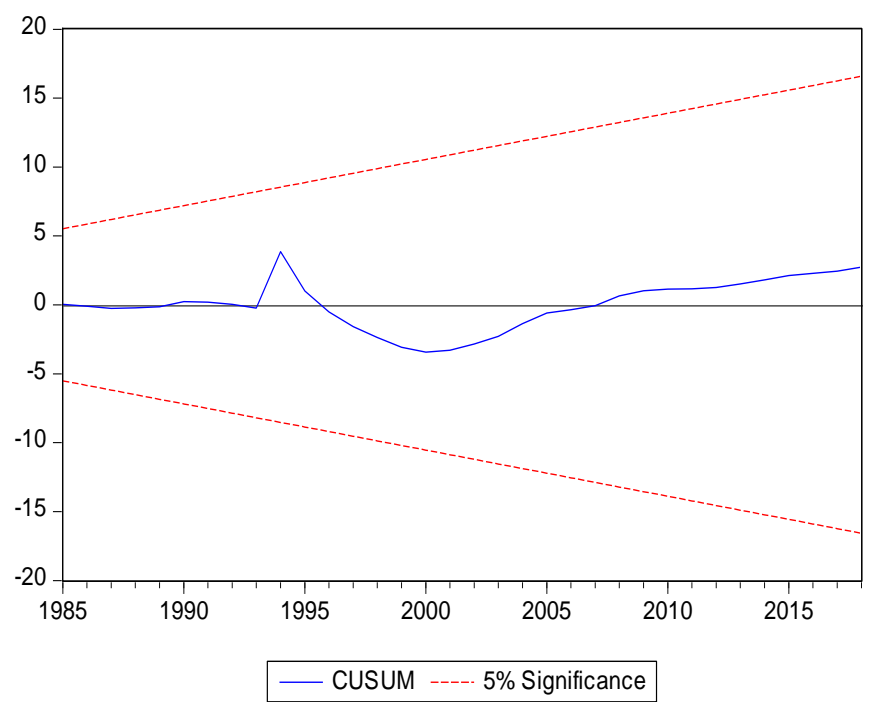

Source: Computer analysis using E-views

To investigate the existence of a possible structural instability, the study used the Cusum test on table 3 and found that the cumulative sum remained within the area between the two critical lines showing that test did not detect any systematic eventual movements and that the coefficients values reflect structural stability.

Table 4: Ordinary Least Square (OLS) Results: Short-Run Analysis

\begin{tabular}{|c|c|c|c|c|}
\hline \multicolumn{5}{|c|}{ Dependent Variable: LOG(RGDP) } \\
\hline \multicolumn{5}{|c|}{ Method: Least Squares } \\
\hline \multicolumn{5}{|c|}{ Sample (adjusted): 19812018} \\
\hline \multicolumn{5}{|c|}{ Included observations: 38 after adjustments } \\
\hline Variable & $\begin{array}{r}\text { Coefficie } \\
\text { nt }\end{array}$ & Std. Error & t-Statistic & Prob. \\
\hline $\mathrm{C}$ & 8.627605 & 0.313910 & 27.48432 & 0.0000 \\
\hline LOG(EXTDT) & $\begin{array}{r}- \\
0.147509\end{array}$ & 0.081793 & -1.803451 & 0.0802 \\
\hline LOG(DMSDT) & 0.629305 & 0.298610 & 2.107448 & 0.0425 \\
\hline LOG(CPS) & $\begin{array}{r}- \\
0.220284\end{array}$ & 0.200687 & -1.097647 & 0.2801 \\
\hline R-squared & 0.701122 & \multicolumn{2}{|c|}{ Mean dependent var } & 10.32956 \\
\hline $\begin{array}{l}\text { Adjusted R- } \\
\text { squared }\end{array}$ & 0.674751 & \multicolumn{2}{|c|}{ S.D. dependent var } & 0.639486 \\
\hline $\begin{array}{l}\text { S.E. of } \\
\text { regression }\end{array}$ & 0.364703 & \multicolumn{2}{|c|}{ Akaike info criterion } & 0.919834 \\
\hline $\begin{array}{l}\text { Sum squared } \\
\text { resid }\end{array}$ & 4.522280 & \multicolumn{2}{|c|}{ Schwarz criterion } & 1.092211 \\
\hline Log likelihood & $\begin{array}{r}- \\
13.47684\end{array}$ & \multicolumn{2}{|c|}{ Hannan-Quinn criter. } & 0.981164 \\
\hline F-statistic & 26.58632 & \multicolumn{2}{|c|}{ Durbin-Watson stat } & 2.076152 \\
\hline Prob(F-statistic) & 0.000000 & & & \\
\hline
\end{tabular}

Source: Computer analysis using EViews 9
From the results of the OLS, the constant parameter (Bo) is positive at 8.627605 .

This means that if all the explanatory variables are held constant, RGDP as a dependent variable will on theaverage increase by 8.63 percent. For EXTDT, the coefficient is 0.147509. This means that EXTDT is negatively related to RGDP. This implies that on the average, one percent increase in EXTDT will on the average lead 0.15 percent decrease in RGDP.The result also shows that the coefficient of DMSDT is 0.629305 . The result showed that on the average, one percent increase in DMSDT will lead to 0.63 percent increase in RGDP. The result equally shows that thecoefficient of CPS is -0.220284 . From the result one percent increase in CPS will lead to 0.22 percent fall in RGDP on the average. The RSquared value of 0.701122 shows that about $70.11 \%$ of the total variation in the dependent variable (RGDP) were explained by changes in the explanatory variables (EXTDT, DMSDT, and CPS). The F-statistic of 26.58632 with the corresponding probability value of 0.000000 measured the adequacy of the regression model and the overall influence of EXTDT, DMSDT and CPS on RGDP. Since P $=0.000<0.05$ (level of significance), the model was a good fit and the explanatory variables (EXTDT, DMSDT and CPS) jointly exerted a statistically significant effect on the dependent variable (RGDP). The Durbin-Watson value of 2.076152 shows the absence of autocorrelation.

The next step is to perform the over parameterised and parsimonious error correction method to account for shortrun dynamic adjustments required for stable long run relationship among the variables in the model. The over parameterized model is presented in table 5. The overparameterized model account for model misspecification problems as a step towards arriving at a preferred or parsimonious model. This is presented below.

Table 5:Over-Parameterised Error Correction Results

\begin{tabular}{|c|c|c|c|c|}
\hline \multicolumn{4}{|c|}{ Dependent Variable: DLOG(RGDP) } & \\
\hline \multicolumn{4}{|c|}{ Method: Least Squares } & \\
\hline \multicolumn{4}{|c|}{ Sample (adjusted): 1984 2018 } & \\
\hline Included observations: 35 after adjustments & Prob. \\
\hline Variable & $\begin{array}{c}\text { Coefficien } \\
\mathrm{t}\end{array}$ & Std. Error & t-Statistic & 0.7609 \\
\hline C & -0.040405 & 0.131152 & -0.308078 & 0.6480 \\
\hline DLOG(EXTDT) & -0.040818 & 0.088173 & -0.462933 & 0.1280 \\
\hline $\begin{array}{c}\text { DLOG(EXTDT(- } \\
1) \text { ) }\end{array}$ & -0.140112 & 0.088596 & -1.581478 & 0.1795 \\
\hline $\begin{array}{c}\text { DLOG(EXTDT(- } \\
\text { 2)) }\end{array}$ & 0.129077 & 0.093109 & 1.386290 & 0.0154 \\
\hline DLOG(DMSDT) & 0.762347 & 0.290128 & 2.627620 & 0.0585 \\
\hline $\begin{array}{c}\text { DLOG(DMSDT(- } \\
\text { 1)) }\end{array}$ & -0.631916 & 0.316593 & -1.995987 & 0.6718 \\
\hline $\begin{array}{c}\text { DLOG(DMSDT(- } \\
\text { 2)) }\end{array}$ & 0.135668 & 0.315933 & 0.429420 & 0.4489 \\
\hline DLOG(CPS) & -0.276139 & 0.358113 & -0.771093 & 0.0099 \\
\hline DLOG(CPS(-1)) & 1.008416 & 0.356935 & 2.825207 & \\
\hline
\end{tabular}




\begin{tabular}{|c|c|c|c|c|}
\hline DLOG(CPS(-2)) & -0.612938 & 0.363578 & -1.685849 & 0.1060 \\
\hline $\begin{array}{c}\text { DLOG(RGDP(- } \\
\text { 1)) }\end{array}$ & 0.317807 & 0.231988 & 1.369926 & 0.1845 \\
\hline $\begin{array}{c}\text { DLOG(RGDP(- } \\
\text { 2)) }\end{array}$ & 0.149545 & 0.116426 & 1.284471 & 0.2123 \\
\hline ECM(-1) & -0.668716 & 0.251706 & -2.656733 & 0.0144 \\
\hline R-squared & 0.890783 & Mean dependent var & 0.046215 \\
\hline $\begin{array}{c}\text { Adjusted R- } \\
\text { squared }\end{array}$ & 0.831210 & S.D. dependent var & 0.557953 \\
\hline S.E. of regression & 0.229230 & Akaike info criterion & 0.170366 \\
\hline Sum squared resid & 1.156016 & \multicolumn{2}{|c|}{ Schwarz criterion } & 0.748067 \\
\hline Log likelihood & 10.01860 & \multicolumn{2}{|c|}{ Hannan-Quinn criter. } & 0.369788 \\
\hline F-statistic & 14.95281 & \multicolumn{2}{|c|}{ Durbin-Watson stat } & 2.098763 \\
\hline Prob(F-statistic) & 0.000000 & \multicolumn{3}{|l}{} \\
\hline
\end{tabular}

Source: Computer analysis using EViews 9

In the over parameterized model as shown in table 5, the error correction term ECM (-1) is correctly specified. It is negative and statistically significant. This means that it will be effective to correct any deviations from the long-run equilibrium. Moreover, the negative and statistically significant of the ECM confirms that the variables in the model are co- integrated The coefficient of the $\operatorname{ECM}(-1)$ which is -0.668716 indicates that the speed of adjustment to long run equilibrium is 66.87 percent when any past deviation must be corrected in the present period. This means that the present value of RGDP adjusts so fast to changes in EXTDT, DMSDT and CPS. The coefficient of determination $\left(\mathrm{R}^{2}\right)$ in the over parameterized model is 0.890783 . This means that about 89.0 percent of the variations in the dependent variable (RGDP) is explained jointly by changes in the explanatory variables in the model. The F-statistic of 14.95281 with probability of 0.000000 is significant. This means that the explanatory variables in the model (EXTDT, DMSDT and CPS) are jointly significant. The Durbin Watson statistic of 2.098763 means the absence of autocorrelation. RGDP in the one lag period is positive and statistically insignificant on current RGDP while RGDP in the two lag periods is also positive and statistically insignificant on current RGDP. This means that RGDP in the one lag period impacts positively and is statistically insignificant on current period RGDP while two lag periods of RGDP also impacts positively and also statistically insignificant on current RGDP. EXTDT in the current period and EXTDT in the one lag period impact negatively and are statistically insignificant on the current RGDP. EXTDT in the two lag periods has a positive impact and is also statistically insignificant on the current RGDP. DMSDT in the current period has a positive and significant impact on the current RGDP.

DMSDT in the one lag period has a negative and statistically insignificant impact on current RGDP while DMSDT in the two lag periods has a positive and statistically insignificant impact on current RGDP.CPS in the current period has a negative and insignificant impact on current RGDP while CPS in the one lag period has a positive and significant impact on current RGDP. CPS in the two lag periods has a negative and statistically insignificant impact on current RGDP.

The next step is to perform the parsimonious model which is a stepwise reduction of jointly insignificant variables in the over parameterized model until parsimony is achieved. In other word, the parsimonious model would be built by estimating the equations of only those variables found to be significant in the over-parameterized model. This is presented in table 6

Table 6: Parsimonious Error Correction Result

\begin{tabular}{|c|c|c|c|c|}
\hline \multicolumn{4}{|c|}{ Dependent Variable: DLOG(RGDP) } & \\
\hline \multicolumn{5}{|c|}{ Method: Least Squares } \\
\hline \multicolumn{5}{|c|}{ Sample (adjusted): 19832019} \\
\hline \multicolumn{5}{|c|}{ Included observations: 37 after adjustments } \\
\hline Variable & $\begin{array}{c}\text { Coefficien } \\
\mathrm{t}\end{array}$ & Std. Error & t-Statistic & Prob. \\
\hline $\mathrm{C}$ & -0.078596 & 0.095764 & -0.820726 & 0.4181 \\
\hline $\begin{array}{c}\text { DLOG(EXT } \\
\text { DT }(-1))\end{array}$ & -0.109003 & 0.076547 & -1.423998 & 0.1644 \\
\hline $\begin{array}{c}\text { DLOG(DMS } \\
\text { DT) }\end{array}$ & 0.827186 & 0.206055 & 4.014396 & 0.0004 \\
\hline $\begin{array}{c}\text { DLOG(DMS } \\
\text { DT(-1)) }\end{array}$ & -0.693536 & 0.252812 & -2.743287 & 0.0100 \\
\hline $\begin{array}{c}\text { DLOG(CPS( } \\
-1)) \\
\end{array}$ & 0.572843 & 0.274592 & 2.086158 & 0.0453 \\
\hline $\operatorname{ECM}(-1)$ & -0.634322 & 0.153126 & -4.142481 & 0.0002 \\
\hline R-squared & 0.846548 & \multicolumn{2}{|c|}{ Mean dependent var } & 0.042191 \\
\hline $\begin{array}{l}\text { Adjusted R- } \\
\text { squared }\end{array}$ & 0.821798 & \multicolumn{2}{|c|}{ S.D. dependent var } & 0.542632 \\
\hline $\begin{array}{c}\text { S.E. of } \\
\text { regression }\end{array}$ & 0.229066 & \multicolumn{2}{|c|}{ Akaike info criterion } & 0.037784 \\
\hline $\begin{array}{l}\text { Sum squared } \\
\text { resid }\end{array}$ & 1.626614 & \multicolumn{2}{|c|}{ Schwarz criterion } & 0.299014 \\
\hline $\begin{array}{c}\text { Log } \\
\text { likelihood }\end{array}$ & 5.301001 & \multicolumn{2}{|c|}{ Hannan-Quinn criter. } & 0.129880 \\
\hline F-statistic & 34.20362 & \multicolumn{2}{|c|}{ Durbin-Watson stat } & 1.562387 \\
\hline $\begin{array}{l}\text { Prob(F- } \\
\text { statistic) }\end{array}$ & 0.000000 & & & \\
\hline
\end{tabular}

SOURCE: Computer analysis using EViews 9

In the parsimonious model as shown in table 6, the error correction term ECM (-1) is correctly specified. It is negative and statistically significant. This means that it will be effective to correct any deviations from the long-run equilibrium. The speed of adjustment which is the coefficient of ECM (-1) is -0.634322 . This shows that about 63.43 percent of short run disequilibrium adjusts back to equilibrium in the long run. This indicates that present value of the dependent variable adjusts slower to changes in the independent variables than what is obtained in the overparameterized model. The coefficient of determination $\left(R^{2}\right)$ in the parsimonious model is 0.846548 . This means that about 84.66 percent of the variations in the dependent variable (RGDP) are explained jointly by changes in the explanatory variables in the model. The F- statistic of 34.20362 with probability of 0.000000 is highly significant. The Durbin Watson statistic of 1.562387 means the absence of 
autocorrelation. The result of the parsimonious model shows that the coefficients of EXTDT (-1) is -0.109003 and is statistically insignificant. This value of the coefficient shows that on the average, one percent increase in the one lag period of EXTDT will lead to 0.11 percent decrease in the current RGDP. The result also reveals that the coefficient of DMSDT is 0.827186 and is statistically significant. The value of the coefficient shows that on the average, one percent increase in the DMSDT in the current period will lead to 0.83 percent increase in the current RGDP. The result equally revealed that the coefficient of DMSDT (-1) is -0.69353 and is statistically significant. The value of the coefficient shows that one percent increase in the one lag period of DMSDT will on the average lead to 0.69 percent fall in the current RGDP. The result equally showed that the coefficient of CPS (-1) is 0.572843 and is statistically significant. The value of the coefficient shows that one percent increase in the one lag period of CPS will on the average lead to 0.57 percent increase in the current RGDP.

\section{SUMMARY}

The impact of public debt on economic growth of Nigeria for the period $1981-2019$ has been examined in this study. The short run regression result showedthat EXTDT has a negative impact on RGDP and was also statistically insignificant. The result also revealed that DMSDT has a positive and significant impact on RGDP while CPS has a negative and insignificant impact on RGDP.The result of the parsimonious model showed that EXTDT in the one lag period has a negative impact on the current RGDP and is also statistically insignificant. The result also showed that DMSDT has a positive impact on the current RGDP and is statistically significant while DMSDT in the one lag period has a negative impact on the current RGDP and is statistically significant. CPS in the one lag period has a positive impact on the current RGDP and is statistically significant. The joint effect of the explanatory variables on the dependent variable was statistically significant implying that these variables were considered important variables in explaining changes in economic growth proxied by RGDP in Nigeria within the period of study. The modeled and operationalized framework of analysis exhibited a very high explanatory power, thereby providing supporting evidence that the explanatory variables included in the model were relevant in explaining changes in economic growth (RGDP) in Nigeria within the period of study.

\section{CONCLUSION}

Given that the joint effect of the explanatory variables on the dependent variable were statistically significant, the study concludes that the components of public debt considered in this study are important variables in explaining economic growth in Nigeria within the period of study.

\section{RECOMMENDATIONS}

Based on the findings, the study recommends that government should reduce the rate at which it takes external loans to finance its activities as the study reveals that external debt has a negative and insignificant impact on the economic growth. Domestic debts should be properly managed bychanneling it towards those activities that will increase capital formation and consequently economic growth.

\section{REFERENCES}

[1] Abel, A.B and Bernanke, B.S (2005). Macroeconomics. Pearson Addison Wesley.

[2] Ajayi, I.E and Edewusi, D.G (2020). An Effect of Public Debt on Economic growth of Nigeria: An Empirical Analysis. International Journal of Business and Management Review, 8(1), 18-38.

[3] Akhanolu, I.A; Babajide, A.A, Victoria, A; Tolulope, O and Godswill, O (2018). Effects of Public Debts on Economic growth in Nigeria: An Empirical Investigation. International Business Management, 12(6), 436-441.

[4] Alagba, O.S and Eferakeya, I (2019). Effect of Public Debt on Economic Growth in Nigeria: An Empirical Analysis 1981-2018. International Journal of Business and Economic Development,7(2), 10-17.

[5] Anyanwu, F.A (2003). Public Finance. CREMD Publishers

[6] Anyanwu, J.C (1993). Monetary Economics: Theory and Institutions. Hybrid Publishers.

[7] Bade, R and Parking, M (2004). Foundations of Macroeconomics. Pearson Addison Wesley

[8] Central Bank of Nigeria Statistical Bulletin 2019.

[9] Chinwoke, N (2014) Public Finance in a developing world. Reconciliation Publishers.

[10] Dewett, K.K and Navalur, M.H (2012). Modern Economic Theory. S. Chand \& Company PVT Ltd.

[11] Egbetunde, T (2012). Public Debt and Economic Growth in Nigeria: Evidence from Granger Causality. American Journal of Economics,2(6), 101-106.

[12] Emmanuel, O.A (2012). An Empirical Analysis of the Impact of Public Debt on Economic growth: Evidence from Nigeria 19752005. Canadian Social Science, 8(4), 154-169.

[13] Favour, E.O; Idenyi, O.S; Oge, E.O and Charity I.A (2017). Public Debt and Economic growth in Nigeria. Asian Journal of Arts \& Social Sciences, 4(3), 1-16.

[14] Jhingan (2010). Money, Banking, International Trade and Public Finance. Vrinda Publications (P) Ltd.

[15] Khan, A.A; Rauf, A; Hag, M and Anwar, N (2016). The Impact of Public Debt on Economic Growth of Pakistan. International Journal of Academic Research in Economics and Management sciences, 5(2), 46-56.

[16] Likita, O (1999). Elements of Public Finance. Abayomi Industrial packaging Ltd.

[17] Mathew, A and Mordecai, B.D (2016). The Impact of Public Debt on Economic Development of Nigeria. Asian Research Journal of Arts \& Social Sciences, 1(1), 1-16

[18] Njoku, P.O (2009) Public Finance. Sources, Administration and Management. El'demak Publishers.

[19] Okafor, J.C and Obasi, A (2011). Fundamentals of Macroeconomics. Hipuks Additional Press.

[20] Samuelson P.A and Nordhaus, W.D (2010). Economics. McGrawHill Education

[21] Tsoulfidis (2007). Classical Economist and Public Debt. International Review of Economics,54(1), 1-12. 